\title{
PENGATURAN DIRI DALAM BELAJAR PADA MAHASISWA DI KOTA MALANG
}

\author{
Atika Zuhrotus Sufiyana \\ Universitas Islam Malang \\ atika.zuh@gmail.com
}

\begin{abstract}
ABSTRAK
Pengaturan diri dalam belajar merupakan upaya yang harus dilakukan seorang pelajar untuk mempermudah dan memperlancar setiap proses belajarnya guna mencapai tujuan yang telah ditetapkan. Artikel ini membahas tentang pengaturan diri dalam belajar (Self Regulation Learning) pada kalangan mahasiswa. Adapaun tujuan penelitian ini untuk mengeksplorasi pengaturan diri dalam belajar mahasiswa melalui metode analisis situasional. Melalui metode ini semua elemen yang mempengaruhi pengaturan diri dalam belajar dapat terpetakan dengan sistematis. Berdasarkan tujuan yang ditetapkan, data diperoleh dari tujuh kelompok pilihan. Sampel penelitian terdiri dari 48 peserta mahasiswa. Adapaun temuan utama penelitian ini berupa dua peta situasional, analisis relasional dan posisi. Hasil penelitian menunjukkan kegunaan analisis situasional serta membuktikan bahwa pengaturan diri dalam belajar tidak dapat dipisahkan dari proses kognitif dan metakognitif.
\end{abstract}

Keywords: Pengaturan diri, Belajar.

\section{PENDAHULUAN}

Kemajuan teknologi informasi dan komunikasi dapat memberikan dampak positif dan negatif pada setiap penggunanya. Pemanfaatannya dapat banyak membantu dan mempermudah seseorang dalam menyelesaikan tugas dan tanggungjawabnya. Sebaliknya, pengguna yang tidak mampu menyerap beragam manfaat kemajuan TIK mendapatakn banyak kerugian dari penggunaan yang berlebihan. Candu terhadap penggunaan gadget, smartphone atau perangkat yang lain menjadikan penggunanya lalai pada kewajibankewajiban yang harus dilaksanakan. Demikian yang terjadi pada kalangan pelajar. Hasil penelitian menunjukkan bahwa gadget memberikan dampak negatif yang lebih besar 
dibandingkan dengan pemanfaatannya pada kalangan pelajar. ${ }^{1}$ Sehingga hal ini menjadi sebuah fenomena yang harus ditindaklanjuti dengan memberikan solusi bagi pelajar untuk dapat mengatur segala aktivitasnya sehingga tidak memberikan kerugian pada dirinya sendiri khususnya.

Pengaturan diri dalam belajar atau yang dikenal dengan self regulation learning merupakan teori yang berindukkan pada teori kognitif sosial Albert Bandura. Teori ini menyatakan bahwa kemampuan mengatur diri sendiri khususnya dalam belajar akan memberikan dampak positif pada kemajuan individu dalam studinya. Dengan membekali para pelajar akan pentingnya memonitor kemajuan hasil belajar secara mandiri maka unsurunsur dalam pengaturan diri harus melekat dalam dirinya sehingga peserta didik dapat dengan mudah mengatur setiap kegiatan yang ia lakukan. Degan demikian setiap waktu yang ia miliki dapat dimanfaatkan dengan baik.

Kemampuan mengatur diri dalam belajar wajib dimiliki oleh setiap mahasiswa karena pantauan orang tua dan para pendidik terbatas pada ruang dan waktu. Para mahasiswa harus memiliki kesadaran diri untuk berupaya mengatur segala proses belajarnya untuk menyelesaikan tugas akademiknya serta untuk mencapai tujuan yang telah ditetapkannya.

\section{METODE}

Tujuan dari penelitian ini untuk menggambarkan situasi belajar yang diatur sendiri (self regulation learning) mandiri di kalangan siswa. Pendekatan penelitian kualitatif dipilih sesuai dengan masalah dan tujuan penelitian. Di sisi lain Penelitian ini menggunakan varian yang berorientasi pada konten. ${ }^{2}$

Kelompok dalam penelitian ini ditentukan langsung dari perguruan tinggi. Kelompok tersebut mencakup total keseluruhan 49 responden dengan rincian 37 wanita dan 12 pria. Kelompok tersebut merupakan mahasiswa tahun ke-3 dalam studi strata 1 (S1). Adapun usia responden berkisar antara 21 hingga 25 tahun. Mahasiswa di tahun

\footnotetext{
${ }^{1}$ Teddy Tri Setio Berty, Peneliti: Remaja yang Gemar main gadget Tidak Bahagia, https://www.liputan6.com/global/read/3238072/peneliti-remaja-yang-gemar-main-gadget-tidak-bahagia diakses 08 Maret 2020

2 D. L. Morgan, Reconsidering the role of interaction in analyzing and reporting focus groups. Qualitative Health Research, 2010. Hal: 718-722. Dan D. L. Morgan, Focus Groups and Social Interaction. In Gubrium J. F. et al. (eds.). The SAGE Handbook of Interview Research. The Complexity of the Craft. (London: Sage Publishing, 2012)
} 
ketiga dipilih karena mereka memiliki pemahaman terhadap cara belajar yang mereka anggap sesuai untuk diri mereka sendiri.

Kegiatan wawancara sendiri dilakukan pada bulan Desember 2019. Wawancara dilakukan pada 7 kelompok yang terdiri dari 6 hingga 10 peserta. Panjang wawancara berkisar antara 60 hingga 80 menit. Kegiatan wawancara ini direkam secara keseluruhan melalui video dan dictaphone. Pertanyaan dan moderasi diskusi dilakukan sesuai dengan naskah yang telah ditentukan oleh dua moderator. Prosedur ini memungkinkan triangulasi peneliti dan mendukung validitas data yang diperoleh. Triangulasi selanjutnya juga diterapkan dalam pemrosesan, analisis dan interpretasi data yang dikumpulkan, yaitu dalam kode dan kategori kontrol bersama.

\section{TEMUAN}

Penelitian ini menemukan bahwa pengaturan diri dalam belajar pada kalangan mahasiswa terdiri dari berbagai komponen yang beragam. Berdasarkan data yang terkumpul, peneliti menemukan terdapat total 38 elemen sebagaimana tertera pada gambar 1 (lihat Gambar. 1) terkait dengan masalah muncul untuk menciptakan lingkungan yang unik untuk belajar mandiri pada kalangan mahasiswa. Dalam hal ini perlu dicatat bahwa pengaturan diri dalam belajar atau belajar mandiri tidak dapat dibatasi hanya pada komponen kognitif dan metakognitifnya, seperti yang dapat ditemukan dalam literatur. ${ }^{3}$ Selain itu, perlu untuk mempertimbangkan lingkungan sosial yang luas, dan tidak hanya lingkungan mikro yang dihasilkan oleh para aktor, yang memfasilitasi atau menghambat proses pembelajaran. ${ }^{4}$

Elemen-elemen ini dapat dikelompokkan lebih lanjut ke dalam 12 kategori (lihat tabel 1) yang mencakup elemen manusia dan elemen non manusia. Elemen manusia mencakup: mahasiswa, dosen, orang tua, teman, serta peneliti yang telah memasuki situasi tersebut. Adapun elemen bukan manusia dalam bentuk berbagai organisasi dan jejaring sosial yang tidak dikonseptualisasikan secara sistematis, karena itu semua tidak berkaitan langsung dengan dimensi kognitif, metakognitif, atau sosial dalam pengaturan diri belajar. Namun dalam analisis posisi yang dipilih (Gbr. 3), elemen material dalam bentuk

${ }^{3}$ P. H. Winne, Students'calibration of knowledge and leasing processes: implications for designing powerful software leasing environments. In: International Journal of Educational Research, 2014. Hal: 468-488.

4 Zimmerman \& Schunk (eds.). Buku pegangan pengaturan belajar dan kinerja mandiri (New York: Routledge, $\mathrm{tt}$ ) hal: 84. 
jejaring sosial (Facebook khususnya) memainkan peran yang sangat penting bagi mahasiswa dalam mengatur belajar mereka. Elemen material ini kadang kala membantu mahasiswa untuk memberikan fasilitas dalam belajar mereka, kadang kala juga mengganggu sehingga mereka dihindari.

$\begin{array}{ccccc}\text { Program } & \text { Strategi } & \text { Motivasi } & \text { Fakultas } & \text { Jejaring Sosial } \\ \text { Studi } & \text { Belajar } & \text { Untuk } & & \text { Belajar }\end{array}$

Teman

Peneliti

\begin{tabular}{|c|c|c|c|c|}
\hline \multirow{2}{*}{ Kelompok } & Mahasiswa & & \multicolumn{2}{|c|}{ Mahasiswa Sekaligus } \\
\hline & Sukses & Kelas & \multicolumn{2}{|c|}{ Pegawai } \\
\hline \multirow{3}{*}{ Belajar } & Gelar & & \multirow[b]{2}{*}{ Pengalaman } & Emosi \\
\hline & Akademik & & & Belaja \\
\hline & & $\begin{array}{l}\text { Hasil } \\
\text { Belajar }\end{array}$ & Kerja & $\mathrm{r}$ \\
\hline \multirow{2}{*}{$\begin{array}{c}\text { Guru } \\
\text { Akademik }\end{array}$} & Mahasiswa & & \multirow[b]{2}{*}{ Orang Tua } & Motivasi Untuk \\
\hline & Lain & Motivasi & & Menyelesaikan \\
\hline \multirow{4}{*}{$\begin{array}{c}\text { Motivasi } \\
\text { Belajar }\end{array}$} & & Dosen & & Studi \\
\hline & Manajemen & & \multirow{3}{*}{$\begin{array}{c}\text { Perguruan } \\
\text { Tinggi }\end{array}$} & \\
\hline & Waktu & Wakt & & Demotivasi \\
\hline & & Belajar & & \\
\hline
\end{tabular}

Gambar 1. Data Acak

Selain kategori-kategori tersebut di atas, terdapat konstruksi diskursif elemen manusia dan non-manusia. ${ }^{5}$ Elemen manusia merupakan representasi yang diberikan oleh mahasiswa kepada dosen mereka serta berkaitan dengan bagaimana mereka melihat diri mereka sendiri. Sedangkan elemen non-manusia mencakup lingkungan dimana mahasiswa banyak berinteraksi, diantaranya: (1) lingkungan pendidikan, di tempat ini mereka memahami pentingnya menimba ilmu dan memiliki gelar akademik, (2) tempat magang, sebagai sarana belajar untuk terjun di dunia kerja. Kedua elemen ini juga muncul pada wacana tentang pekerjaan dan pendidikan tinggi (lihat tabel 1).

${ }^{5}$ B. Latour, (2005). Reassembling the Social. An Introduction to Actor-Network Theory. Oxford: Oxford University Press. 
Dimensi kognitif dan metakognitif dalam belajar mandiri (self regulation learning) meliputi motivasi, manajemen waktu, strategi belajar, evaluasi dan emosi. Emosi menjadi bagian yang tidak kalah penting untuk mensukseskan program belajar mandiri. Emosi dalam hal ini dapat dikategorikan kedalam tiga bagian: (1) emosi yang terkait dengan program studi, (2) emosi yang terkait dengan pembelajaran, dan (3) emosi yang terkait dengan ujian.

\begin{tabular}{|c|c|c|}
\hline Faktor manusia & $\begin{array}{l}\text { Struktur individu dan } \\
\text { kolektif }\end{array}$ & Elemen waktu \\
\hline Mahasiswa & Mahasiswa & Manajemen waktu \\
\hline Dosen & Mahasiswa yang gagal & Waktu belajar \\
\hline Orangtua & Mahasiswa yang sukses & \\
\hline Teman & Keberhasilan kerja mhsiswa & \\
\hline \multirow[t]{2}{*}{ Peneliti } & Motivasi dosen & \\
\hline & Demotivasi dosen & \\
\hline Faktor non-manusia & Elemen non-manusia & Elemen spasial \\
\hline Universitas & Mahasiswa plus pekerja & Jarak dari tempat tinggal - \\
\hline Sekolah & Tempat praktik magang & perjalanan \\
\hline Jejaring & Sekolah Menengah & \\
\hline (Facebook) & Universitas & \\
\hline \multirow[t]{2}{*}{ Universitas lain } & Program belajar & \\
\hline & Gelar akademik & \\
\hline Ragam Komunitas & Motivasi & Manajemen pembelajaran \\
\hline Kelas & Motivasi untuk berpartisipasi & Strategi belajar \\
\hline \multirow[t]{4}{*}{ Kelompok teman sekelas } & dalam program studi & Hasil belajar \\
\hline & Motivasi belajar & \\
\hline & Motivasi & \\
\hline & menyelesaikan studi & \\
\hline Faktor implisit & Emosi & Orientasi masa depan \\
\hline $\begin{array}{l}\text { Sistem pendidikan di } \\
\text { perguruan } \\
\text { tinggi/universitas }\end{array}$ & $\begin{array}{l}\text { Emosi terkait dengan } \\
\text { program studi } \\
\text { Emosi terkait dengan belajar } \\
\text { Emosi yang terkait dengan }\end{array}$ & $\begin{array}{l}\text { Wacana tentang pekerjaan } \\
\text { Wacana tentang pendidikan } \\
\text { tinggi }\end{array}$ \\
\hline
\end{tabular}


ujian

Tabel. 1

\section{Analisis Relasional}

Penggunaan dan pemilihan strategi pembelajaran merupakan hal penting dalam pengaturan diri dalam belajar (self regulation learning). ${ }^{6}$ sehingga pemilihan penggunaan analisis relasional dipilih sebagai analisis yang sesuai dengan tema pembahasan ini. Diagram di bawah ini (Gbr. 2) menunjukkan beberapa elemen yang memiliki hubungan langsung dengan strategi belajar. Penjelasan secara lebih rinci tentang hubungan antara strategi pembelajaran dan elemen individu akan dipaparkan kemudian.

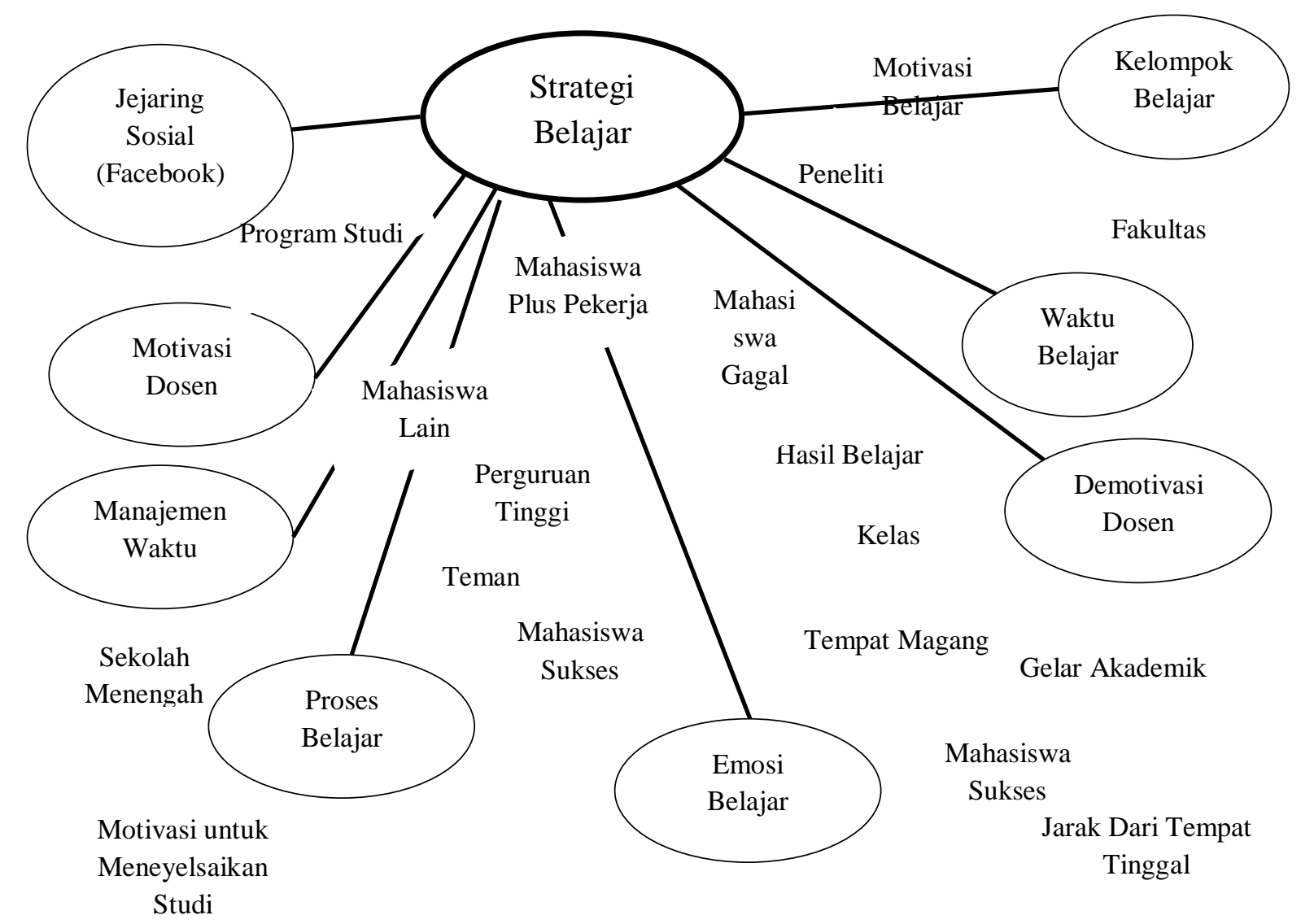

Gambar 2. Analisis Relasional

\footnotetext{
${ }^{6}$ P. H. Winne, Students'calibration, hal: 477
} 
Motivasi untuk belajar mempengaruhi strategi belajar mahasiswa, wujud dari motivasi tersebut adalah kesediaan mahasiswa untuk mengisi waktu mereka untuk belajar sebelum ujian tiba. Adapun bagi mahasiswa yang tidak termotivasi untuk belajar dengan alasan tidak menikmati proses belajar mereka dapat diketahui bahwa mereka kurang atau bahkan tidak termotivasi sehingga mereka merasa bahwasanya melakukan aktivitas belajar merupakan suatu beban sehingga mereka berikan sisa-sisa waktu mereka untuk belajar.Error!

\section{Bookmark not defined.Error! Bookmark not defined.Error! Bookmark not defined.Error! Bookmark not defined.Error! Bookmark not defined.Error! Bookmark not defined.}

Mahasiswa yang memiliki motivasi tinggi merasa puas dengan upaya yang mereka berikan untuk kemajuan belajarnya, salah satu diantara mereka mengatakan bahwa: "ketika melihat teman-teman yang lain bersenang-senang menghabiskan waktu untuk bersenangsenang, saya termotivasi untuk belajar untuk hasil yang lebih baik". Sebaliknya, mahasiswa yang tidak meikmati studi mereka menyatakan bahwa: "Tidak banyak yang terjadi pada saya ketika saya hanya duduk dan mulai membaca. Saya hanya kurang motivasi" . Sebagian dari mereka juga mengatakan: "Saya belajar apa yang menarik minat saya. Apa yang saya tidak suka, saya tidak pelajari lebih dalam”.

Namun dalam proses belajar yang kurang termotivasi seperti di atas ternyata terdapat mahasiswa yang mampu memberikan penguatan (reinforcement) dalam belajar mereka. Hal ini merupakan salah satu cara memberikan motivasi kepada diri sendiri. Mereka menyatakan: " Saya berjanji pada diri sendiri untuk memiliki atau membeli sesuatu yang saya inginkan seperti, coklat, baju, sepatu dan sebagainya”. Strategi yang demikian banyak digunakan untuk memenuhi tugas tertentu atau untuk mempersiakan ujian dan cara ini menjadi alternatif untuk mereka yang kurang termotivasi dalam belajarnya.

Selain menggunakan penguatan (reinforcement) terdapat faktor lain yang mempengaruhi motivasi mereka yakni kepribadian dosen. Dosen yang dapat memotivasi mahasiswanya mampu memberikan pengaruh sehingga mahasiswa lebih bersemangat untuk belajar. Sebaliknya, dosen yang diidentifikasi oleh mahasiswa sebagai dosen yang tidak mampu membangkikan semangat tidak berdampak pada motivasi belajar. Salah satu mahasiswa mengatakan: "saya tidak tahu apa yang sebenarnya dosen inginkan, mereka mengatakan sesuatu yang tidak saya mengerti, selain itu beliau secara personal pun tidak menarik, sehingga saya tidak melakukan apa-apa untuk belajar saya”. 
Elemen lain yang mempengaruhi strategi belajar adalah pemilihan waktu belajar. Terdapat dua jenis pemilihan waktu belajar di kalangan mahasiswa. Pertama, mereka memilih belajar di pagi hari sebelum siang hari. Mereka menyatakan bahwa waktu tersebut merupakan waktu yang sangat mereka sukai untuk belajar. Selain pada waktu tersebut mereka menyatakan bahwa hasilnya akan tidak sebaik belajar di pagi hari. Adapun tipe kedua belajar d malam hari. Mereka berpendapat bahwa kondisi optimal untuk belajar selalu di malam hari. Diantara mahasiswa menyatakan bahwa: "saya lebih cepat memahami materi pada malam hari dibandingkan belajar di pagi hari, dan saya akan benar-benar mengingatnya".

Selain elemen di atas, salah satu prasyarat penting belajar mandiri yang efektif adalah manajemen waktu. Banyak mahasiswa tidak dapat mulai mempersiapkan ujian jauh sebelum pelaksanaanya. Mereka merasa kesulitan untuk mempersiapkan ujian pada jauh-jauh hari. Mereka menyatakan bahwa: "saya tidak dapat belajar jika waktu ujian masih lama, akhirnya materi kuliah menumpuk dan itu sangat banyak yang belum saya pelajari. Mahasiswa dalam tipe ini memiliki sedikit waktu untuk belajar, dan hasil belajarnya pun tidak optimal. Tidak ada yang kurang tepat, hasil ini dapat dipertanggungjawabkan oleh fakta bahwa mereka tidak termotivasi untuk belajar. Dalam wawancara peelitian ini ditemukan dua pendapat tentang organisasi waktu dan strategi pembelajaran, yang pertama dipegang oleh mahasiswa yang mengklaim bahwa mereka tidak perlu mengelola dan merencanakan proses belajar. Mereka memilih untuk belajar pada waktu-waktu ujian hampir tiba. Dengan keterbatasan waktu tersebut mereka dengan sadar harus belajar dengan sungguh-sungguh. Mereka mengatakan bahwa "Meskipun saya tahu bahwa saya harus mulai belajar lebih awal, itu tidak mungkin. Saya perlu tahu bahwa ini adalah kebutuhan yang membara, saya suka belajar SKS (sistem kebut semalam)". Pendapat kedua mereka adalah para mahasiswa yang membutuhkan lebih banyak waktu untuk mempersiapkan ujian dengan belajar di jauh-jauh hari. Hal ini mereka lakukan untuk menghindari kecemasan dan stres belajar pada saat terakhir, yang mengurangi efektivitas belajar mereka. Mereka mengatakan bahwa: "Saya melakukan banyak persiapan sebelumnya. Saya perlu mengulangi banyak. Saya tipe orang yang banyak stres".

Emosi mempengaruhi strategi pembelajaran dalam dua hal penting. Pertama adalah emosi yang berkaitan dengan ujian yang memotivasi mahasiswa untuk mempersiapkan diri secara lebih intensif. Mahasiswa ingin menghindari kemungkinan rasa malu di mata temanteman sekelas mereka yang akan datang karena gagal dalam ujian: "Saya tidak ingin terlihat bodoh di depan seluruh kelas saya. Terus terang saja, penting bagi saya untuk tidak melihat 
bodoh". Kedua, emosi yang berhubungan langsung dengan materi/mata kuliah. Seperti ketika mahasiswa menekankan bahwa mereka harus berusaha untuk siap bahkan untuk mata pelajaran yang tidak mereka sukai sama sekali. Dalam hal ini, mereka harus mengatasi emosi negatif yang terkait dengan mata kuliah atau dosen tertentu dan memulai proses belajar. Seorang mahasiswa dalam konteks ini, misalnya menyatakan:"jika seorang mahasiswa tidak dapat mengatasi permasalahan dengan dosen dalam hal materi kuliah atau mungkin tidak mengikuti aturan yang dibuat olehnya, maka ia akan mengalami perjuangan yang mengerikan untuk mempelajari mata kuliah tersebut".

Bagi sebagian mahasiswa, jaringan sosial berfungsi sebagai sumber belajar yang penting dan mempengaruhi strategi belajar mereka. Di satu sisi, jejaring sosial berfungsi sebagai sumber informasi yang digunakan untuk belajar bersama dan berbagi pengalaman dengan teman kelas mereka. Melalui media sosial juga mereka dapat saling berbagi perasaan (emosi) tentang belajar dan pengalaman ujian. Dengan cara ini mereka lebih mampu mengatasi stres dan emosi negatif yang muncul, seperti perasaan kurang berminat mempelajari mata kuliah. Namun, demikian terdapat perbedaan dalam memanfaatkan media sosial pada kalangan mahasiswa. Pada gambar 3 di bawah ini menampilkan tinggi dan rendahnya posisi gaya belajar melalui media sosial.

Selain pemanfaatan media sosial terdapat faktor penting lain yang berperan aktif menentukan keberhasilan pengaturan diri dalam belajar (self regulation learning) yakni kelompok belajar. Kelompok belajar dari teman kelas ini banyak memberikan kontribusi dalam belajar mahasiswa di dalamnya, khususnya saat mereka mempersiapkan untuk ujian tengah semester atau akhir semester. Namun demkian, strategi ini tidak digunakan oleh semua mahasiswa (lihat Gambar 3) meski dampak positifnya cukup besar untuk membantu kemudahan mereka dalam memahami suatu tema mata kuliah. Diantaranya mereka

mengatakan bahwa: "Teman saya yang paham pelajaran selalu membantu saya, mereka dapat menjelaskan pelajaran dengan sederhana dan saya tidak malu untuk terus bertanya ketika saya belum memahaminya”.

\section{Analisis Posisi}

Analisis posisi di bawah ini merupakan gambaran pembelajaran kolaboratif dalam pembelajaran mandiri atau pengaturan diri dalam belajar. Hasil analisis ini berdasarkan hasil penelitian yang dilakukan terhadap para mahasiswa mengenai strategi belajarnya selama tiga tahun terakhir. Analisis posisi ini fokus pada penggunaan strategi belajar kolaboratif yang dianggap oleh beberapa ahli (Järvelä et al., 2013; Mikkänen, Perrry \& Järvelä, 2015) sebagai 
salah satu domain inti pembelajar yang diatur sendiri atau belajar mandiri. Selain itu pembelajaran kolaboratif banyak mempengaruhi keefektifan upaya belajar mandiri sehingga memberikan dampak terhadap hasil belajar.

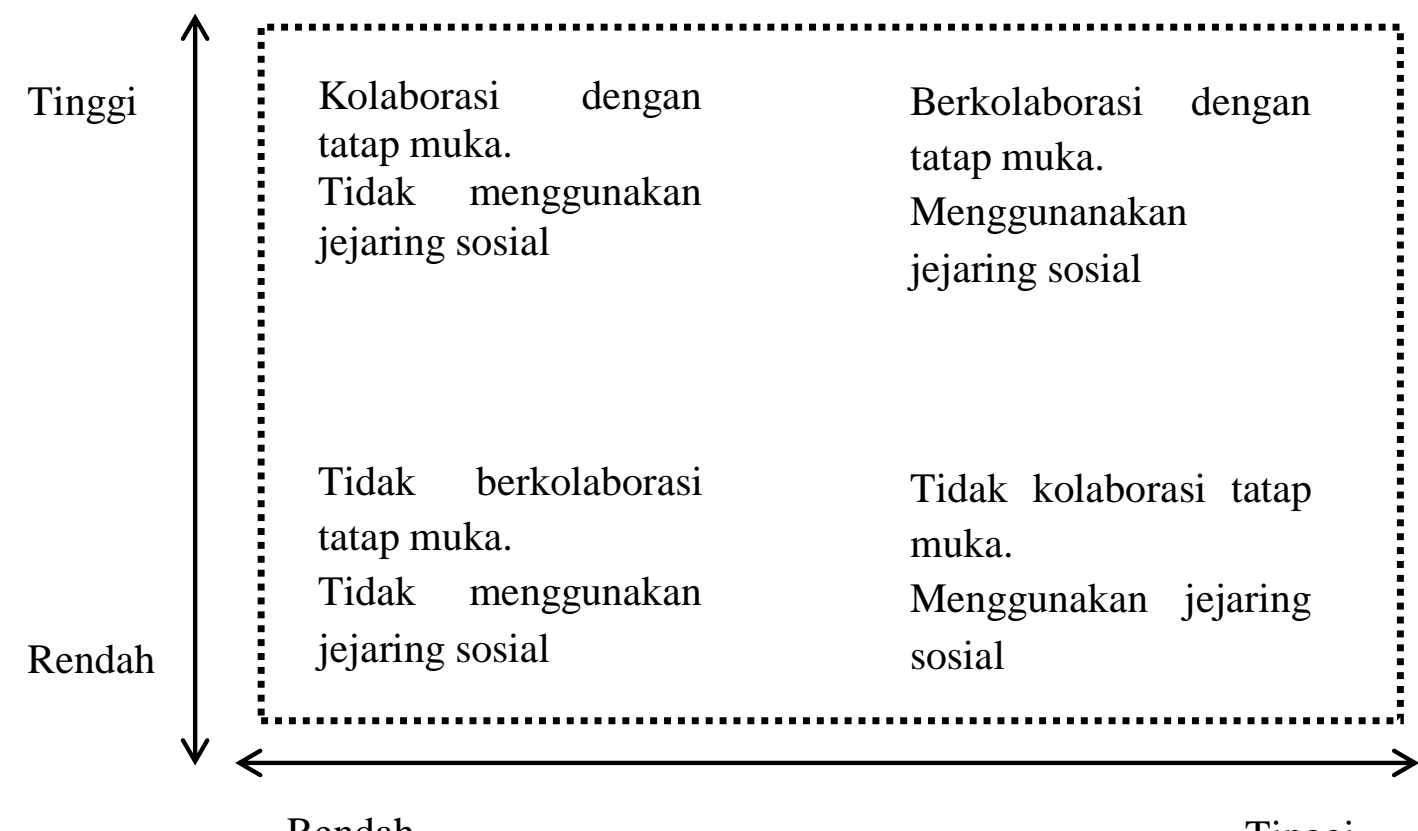

Rendah

Tinggi

Gambar 3. Level Pembelajaran

Menggunakan Jejaring Sosial

Menurut beberapa ahli tidak semua mahasiswa dapat berkolaborasi dengan cara yang sama dalam belajar. ${ }^{7}$ Melalui analisis ini dapat diidentifikasi dua macam gaya belajar mahasiswa. Pertama, mahasiswa belajar melalui sosial media. Kedua, mahasiswa belajar dengan cara kolaborasi dan bertatap muka langsung dengan teman sekelasnya. Berdasarkan dua macam gaya belajar di atas melahirkan empat tipe gaya belajar sebagaimana dalam gambar 3 di atas.

Berdasarkan dua macam gaya belajar di atas melahirkan empat tipe gaya belajar mahasiswa (lihat Gambar 3). Kelompok pertama, kelompok terkecil, terdiri dari mereka yang tidak menggunakan jejaring sosial ketika belajar namun mereka belajar berkolaborasi

${ }^{7}$ P. Dillenbourg, What do you mean by collaboratuve learning? (Oxford: Elsevier, 1999). Hal: 19 lihat juga Malmberg et al. Promoting socially shared regulation of learning in CSCL: Progress of socially shared regulation among high-and low-performing groups. (Computer in Human Behavior, under press, 2015). 
bersama teman-temannya. Para mahasiswa ini menekankan bahwa untuk belajar dengan konsentrasi mereka perlu berada di tempat yang hening dan sunyi serta tidak diganggu oleh siapa pun atau dalam bentuk apapun. Hal ini ditandai dengan pernyataan salah satu peserta dalam penelitian yang menyatakan bahwa:"Ketika saya ingin belajar, saya mematikan TV dan komputer. Jika saya harus belajar, saya harus memiliki ketenangan pikiran dan situasi”.

Kelompok lain terdiri dari mahasiswa yang suka belajar sendiri dan juga memerlukan persiapan yang tenang, tetapi pada saat yang sama mereka menggunakan jejaring sosial untuk mengetahui bagaimana teman sekelas mereka belajar dan memiliki perasaan yang sama bahwa mereka tidak belajar sendiri untuk mempersiakan ujian. Salah satu peserta mengatakan bahwa: "menghubungi teman-teman yang sedang mempersiapkan ujian seperti saya membuat hati saya lebih tenang. Selain itu saya juga merasa bahwa teman-teman yang lain pun panik seperti saya. Namun yang jelas dengan saling bertukar kabar membuat saya lebih tenang". Selain untuk menghubungi teman, terdapat beberapa mahasiswa yang memanfaatkan media sosial sebagai sarana untuk mendapatkan bahan atau materi pelajaran.

Posisi ketiga terdiri dari mahasiswa yang perlu belajar bersama teman-temannya untuk memberikan pemahaman terhadap materi pelajaran. Mahasiswa ini menghindari penggunaan jejaring sosial sebagai sumber belajar karena mereka merasa khawatir akan mengakses media sosial sehingga membuat proses belajar menjadi tidak efektif bahkan tertunda. Hal ini dapat diketahui melalui wawancara mahasiswa yang mengatakan bahwa: "Bagi saya Facebook adalah surga penundaan. Sehingga saya tidak mengizinkan diri saya untuk mengakses Facebook, karena pasti saya tidak akan jadi belajar. Saya akan terus menonton apa yang dilakukan orang lain di Facebook, dan itu tidak baik".

Kelompok terakhir merupakan kelompok yang sangat menyukai belajar bersama kelompok sekelasnya serta memanfaatkan momen ini untuk menyamakan persepsi atas pemahaman materi. Selain itu, mahasiswa dalam kelompok ini juga aktif menggunakan jejaring sosial. Mereka mengakatakn bahwa:"Tentu saja, bagi saya jejaring sosial adalah jalur kehidupan. Saya akan tersesat jika meninggalkannya. Melalui jejaring sosial saya cukup hanya menulis maksud materi yang saya tidak mengerti dan teman-teman saya akan membalas dengan cukup singkat namun jelas. Cara yang saya gunakan sangat membantu belajar saya, bahkan saya akan tahu teman-teman saya yang sama-sama kurang memahami materi dan melalui sosial media tersebut kami akan bertemu dan membahas materi tersebut".

Berdasarkan hasil analisis posisi di atas dapat dipahami bahwasanya dalam rutinitas belajar mahasiswa, mereka menggunakan gaya belajar yang berbeda-beda serta pencarian sumber belajar yang berbeda pula. 


\section{SIMPULAN}

Dari serangkaian analisis di atas membuktikan bahwa teori situasional adalah alat yang berguna untuk memahami pengaturan diri dalam belajar, karena dengan teori ini memungkinkan seseorang untuk mengamati pengaturan diri dalam belajarnya tidak terbatas pada jenis perilakunya saja, tetapi juga menangkap semua elemen yang muncul dalam belajar mandiri. Selain itu, dengan analisis situasional ini data yang diperoleh dari pembelajaran yang diatur sendiri tidak berkurang tetapi dibiarkan dalam kompleksitas penuh. Hal tersebut terlihat jelas dalam jumlah komponen sosial (lihat gambar 1 dan tabel 1) yang baik secara langsung atau tidak langsung terdapat campuran proses kognitif dan metakognitif yang terkait dengan pembelajaran. Lingkungan mahasiswa dalam konteks ini sangat kompleks dan mencakup dua faktor nyata yakni faktor manusia dan non manusia. Mahasiswa berhubungan langsung dan tidak langsung, cepat maupun lambat terhadap dua faktor tersebut. Seperti mahasiswa tidak hanya membutuhkan simbol-simbol akademik berupa gelar akademik, namun mereka pun memiliki harapan untuk pekerjaannya di masa mendatang serta hal-hal lain yang sangat kompleks. Berdasarkan paparan tersebut menunjukkan bahwa belajar mandiri dengan gaya belajar kolaboratif tidak terlepas dari struktur budaya mahasiswa.

Adapun mengenai motivasi dan emosi mahasiswa yang selalu berhubungan dengan konteks tertentu, memiliki makna yang berbeda pada setiap situasi. Sehingga dalam konteks ini, peneliti tidak dapat membahas emosi dan motivasi secara umum, namun harus dikaitkan dengan hal-hal yang lebih spesifik yang terkait erat dengan sumbernya (aktor, peristiwa, proses dan makna) dan yang secara substansial memiliki perbedaan yang mencolok. 


\section{REFERENSI}

B. Latour, (2005). Reassembling the Social. An Introduction to Actor-Network Theory. Oxford: Oxford University Press.

D. L. Morgan (2012). Focus Groups and Social Interaction. In Gubrium J. F. et al. (eds.). The SAGE Handbook of Interview Research. The Complexity of the Craft. London: Sage Publishing.

Malmberg et al. (2015). Promoting socially shared regulation of learning in CSCL: Progress of socially shared regulation among high-and low-performing groups. Computer in Human Behavior, under press.

Morgan, D. L. (2010). Reconsidering the role of interaction in analyzing and reporting focus groups. Qualitative Health Research,

P. Dillenbourg, (1999). What do you mean by collaboratuve learning? Oxford: Elsevier.

Teddy Tri Setio Berty, Peneliti: Remaja yang Gemar main gadget Tidak Bahagia, https://www.liputan6.com/global/read/3238072/peneliti-remaja-yang-gemar-main-gadgettidak-bahagia diakses 08 Maret 2020

Winne, P. H. (2014). Students'calibration of knowledge and leasing processes: implications for designing powerful software leasing environments. In: International Journal of Educational Research,

Zimmerman \& Schunk (eds.). Buku pegangan pengaturan belajar dan kinerja mandiri, New York: Routledge. 